\title{
HRD Climate Dimensions in Commercial Bank of Ethiopia
}

\author{
Anil Kanamarlapudi and Dr. Ramadevi Vangapandu
}

\begin{abstract}
In the present day fierce competitive environment, the forward looking organizations are giving utmost care to attract, develop and retain the best talent as people are considered to be the source of competitive advantage. In order to survive and thrive in the competitive environment, the organizations are keen to develop the competencies of the people and are giving importance to Human Resource Development (HRD). The main objective of the research paper is to study different dimensions of HRD climate in Commercial Bank of Ethiopia (CBE). The scope of the study is confined to 10 branches of $C B E$ and the sample for the study constitutes 190 staff. The results of the study indicated that Collaboration among the employees of CBE is high followed by Trust and Openness and autonomy is considered to be the least. The study also revealed that there is significant difference in HRD dimensions - authenticity, autonomy, collaboration, confrontation and trust dimensions between the branches of $C B E$ while $F$-value is insignificant for openness and pro-action dimensions indicating that openness and pro-action dimensions of HRD climate do not significantly differ between the branches of $C B E$.
\end{abstract}

Keywords--- HRD Climate, HRD Dimensions, Commercial Bank of Ethiopia

\section{INTRODUCTION}

$\mathrm{T}$ HE rise or fall of the organization depends upon its people. Irrespective of the size and type of the organization whether it is an educational institution, a retailing store, a government institution, a hotel, a manufacturing unit or a bank always looks for good, competent and selfmotivated work force. It is strongly believed that people constitute the vital source of the competitive advantage for the present organizations. In the context of the challenges faced by the organizations in the dynamic competitive environment, organizations are trying to attract best talent, develop and retain them. In accordance with the dynamic environment, the competencies required from the employees are also changing. Updating the capabilities and learning new skills is the need of the hour for the existing workforce. Every individual

Anil Kanamarlapudi, Department of Business Studies, Ibra College of Technology, Ibra, Sultanate of Oman. E-mail: kanil_mba@yahoo.co.in

Ramadevi Vangapandu ,Professor, School of Management Studies, vignan University, Vadlamudi, Guntur, A.P. E-mail:vangapanduramadevi1970@gmail.com

DOI: 10.9756/BIJIEMS.4712 employee is required to acquire and update his/ her skills, knowledge and capabilities from time to time in the organization for the effective performance of their job tasks. The primary goal of HRD is to maximize the efficiency of the existing workforce for increasing their overall performance that can lead to the improvement of the entire organization's performance. The HRD climate in an organization depends upon various dimensions like Openness, Confrontation, Trust, Autonomy, Pro-action, Authenticity and Collaboration (OCTAPAC). If these dimensions are perceived to be good in an organization, then the overall HRD Climate would be considered to be effective. In this context the present study is undertaken to study the HRD climate dimensions in Commercial Bank of Ethiopia.

\section{A. Conceptual Framework of HRD}

Swanson, R. A. (2001) [14] described HRD as "a process of rising human capability for improving the performance of individual workforce through the course of personal training \& over all organizational development and is all about "qualitative improvement of human beings in their specific roles of an organization".

"HRD deals with the provision of learning and development opportunities that encourage the achievement of business strategies and improvement of organizational, team and individual performance". (Armstrong, M. and Baron, A., 2002)[4]

Harrison, R., and Kessels, J. W. M. (2004) [6] defined HRD as "an organizational process comprising the skillful planning and facilitation of a variety of formal and informal learning and knowledge processes and experiences, primarily but not exclusively in the workplace, in order that organizational progress and individual potential can be enhanced through the competence, adaptability, collaboration and knowledge-creating activity of all who work for the organization".

\section{LITERATURE SURVEY}

\section{A. HRD Dimensions}

The survey of HRD Climate was established taking the bases of the different HRD Dimensions of "OCTAPAC" (Openness, Confrontation, Trust, Autonomy, Pro-action, Authenticity and Collaboration) by Rao T. V. and Abraham, E. (1986) [9]. This is a popular instrument which is used extensively based on 38 items encompassing "OCTAPAC" dimensions and HRD mechanisms.

Riyaz, R. (2002) [10] carried out a study in commercial banks for analyzing the HRD Climate and found that there 
was a moderate level of overall OCTAPAC scores in all the sample banks. Famina, A. S. (2009) [5] conducted a research study to ascertain the organization climate of Kerala State Financing Enterprise (KSFE) and to understand and analyze the various dimensions of OCTAPAC. The results revealed that KSFE scored high in openness, confrontation, authenticity and collaboration. The Mean Score analysis has shown Proaction, Collaboration and experimentation to be the highest. The factors which scored low are trust and autonomy. Saraswathi, S. (2010) [11] carried out a comparative study among the software and manufacturing organizations. The author revealed that the over-all HRD climate in the software organizations is better compared to the manufacturing companies.

Akinyemi, B. O. (2011) [2] explored the nature of developmental climate in two leading Rwanda based telecommunication and insurance companies. The results indicated that HRD general climate existing in both organizations is amiable, although, it is relatively better in the telecommunication than it is in the insurance company. The overall mean score for OCTAPAC culture is 3.81 and 3.23 for telecommunication and insurance companies respectively. This depicts better OCTAPAC culture in the telecommunication company when compared to the insurance company.

Mohanty, B., et al. (2012) [7] in their study on HRD climate in private insurance sector in Odessa observed that the average mean score of General Climate and OCTAPAC culture was 3.82 and 3.67 respectively and there is significant positive relationship of General Climate, HRD Mechanisms and OCTAPAC Culture with overall HRD Climate.

The employees and the customers integration towards the organizational goals is an important task in HRD. It was opined by Petridou, E. and Glaveli, N. (2003) [8] that the development of human resources and the cost involvement for such activity in the banking organization is considered as an asset rather than cost. Similarly, Anil, K. (2007) [3], in his key note address highlighted that "HRD played a vital role in converting a downswing into an upswing in India with special reference to a bank in the public sector organization. In his study he found that the human resource development has made the transformation process more effectively with the help of human resources for the intended success.

Srimannarayana, M. (2007) [13] reviewed the prevailing HRD climate in Dubai organizations and concluded that the climate is at an average level and HRD climate in banking business is higher than the other businesses. Saxena, K. and Tiwari, P. (2009) [12] observed that the HRD Climate was found to be average in the sample public sector bank. The study also highlighted that the perception of employees did not significantly associate with the selected demographic profiles like gender, education etc. A study of HRD Climate in Nigerian commercial banks (Akinyemi, B. O. and Iornem, D. 2012) [1] has shown a congenial HRD Climate.

The Literature survey reveals that studies on HRD Climate were conducted in different types of organizations like banks, financial enterprises, software, manufacturing, telecommunication and insurance companies. Irrespective of the type of the organization all the studies conducted were based on the dimensions of OCTAPAC in order to assess HRD Climate. The OCTAPAC dimensions are considered to be reliable to assess the HRD climate. The present study is also conducted using OCTAPAC dimensions with respect to Commercial Bank of Ethiopia. Till now, no study has been conducted on the HRD climate of the CBE and hence, the present study is undertaken to study HRD climate dimensions in $\mathrm{CBE}$.

\section{Methodology}

A. Objectives of the Study

1. To study different dimensions of HRD climate in Commercial Bank of Ethiopia

2. To determine if there is a significant difference in the opinions expressed by different respondents regarding various dimensions of HRD climate.

3. To study the relationship between demographic variables of the respondents and opinions expressed towards HRD climate dimensions.

\section{B. Hypotheses of the Study}

1. Null Hypothesis: There are no significant differences in HRD climate dimensions between different branches of Commercial Bank of Ethiopia

Alternate Hypothesis: There are significant differences in HRD climate dimensions between different branches of Commercial Bank of Ethiopia

2. Null Hypothesis: There is no significant relationship between demographic variables of the respondents and opinions expressed towards HRD Dimensions.

Alternate Hypothesis: There is significant relationship between demographic variables of the respondents and opinions expressed towards HRD Dimensions.

\section{Scope of the Study}

The study is conducted in Commercial Bank of Ethiopia, Ethiopia. The bank is well established with wide spread branches in different places in Ethiopia. The study covers HRD climate in ten different branches of Commercial Bank of Ethiopia The study of HRD climate envelops HRD dimensions prevailing in Commercial bank of Ethiopia.

The present study is investigative in nature and seeks to evaluate the effectiveness of HRD climate in the branches of Commercial bank of Ethiopia present in the Diredawa District.

\section{Sample Description}

The universe for the study consists of 17 branches of Commercial Bank of Ethiopia namely Dechatu, Dire Dawa, Gelemso, Gode, Deghabour, Magala, Harar, Jegol, Haramaya, Chiro, Fugnanbira, Kebridar, Dedder, Hirna, Grawa, Toguchali and Jigiga. The total population in these 17 branches and the District Office consists of 461 employees categorized into clerical (277) and non-clerical (184) staff. The scope of the study is confined to ten branches namely 
Dechatu, Dire Dawa, Magala, Harar, Jegol, Haramaya, Chiro, Dedder, Hirna, Jigiga, and the District Office. Out of 10 branches and the District Office which consist of 371 employees categorized into clerical (242) and non-clerical (129) staff, the sample size of 190 consisting of clerical staff including managers was chosen using stratified disproportionate random sampling technique. Non- clerical staff was not included in the sample respondents as they constitute drivers, janitors, attendants, and servant maids. The details of the sample are provided in Table 1.

Table 1: Detail of Sample Branches of Commercial Bank of Ethiopia and Sample Respondents

\begin{tabular}{|c|c|c|c|c|c|c|c|}
\hline S.No & Place & $\begin{array}{c}\text { Branch } \\
\text { Name }\end{array}$ & Grade & $\begin{array}{c}\text { No. } \\
\text { of } \\
\text { employee }\end{array}$ & $\begin{array}{c}\text { Clerical } \\
\text { staff }\end{array}$ & $\begin{array}{c}\text { Non- } \\
\text { clerical } \\
\text { staff }\end{array}$ & Sample \\
\hline 1 & $\begin{array}{c}\text { Dire } \\
\text { Dawa }\end{array}$ & $\begin{array}{c}\text { District } \\
\text { Office }\end{array}$ & Nil & 30 & 21 & 9 & 13 \\
\hline 2 & Chiro & Chiro & 3 & 27 & 18 & 9 & 14 \\
\hline 3 & $\begin{array}{c}\text { Dire } \\
\text { Dawa }\end{array}$ & $\begin{array}{c}\text { Dechat } \\
\text { u }\end{array}$ & 3 & 37 & 25 & 12 & 19 \\
\hline 4 & $\begin{array}{c}\text { Dedd } \\
\text { er }\end{array}$ & Dedder & 1 & 17 & 8 & 9 & 6 \\
\hline 5 & $\begin{array}{c}\text { Dire } \\
\text { Dawa }\end{array}$ & $\begin{array}{c}\text { Dire } \\
\text { Dawa }\end{array}$ & 4 & 82 & 57 & 25 & 50 \\
\hline 6 & Hirna & Hirna & 1 & 17 & 7 & 10 & 5 \\
\hline 7 & $\begin{array}{c}\text { Dire } \\
\text { Dawa }\end{array}$ & Magala & 2 & 28 & 18 & 10 & 14 \\
\hline 8 & $\begin{array}{c}\text { Hara } \\
\text { maya }\end{array}$ & $\begin{array}{c}\text { Haram } \\
\text { aya }\end{array}$ & 2 & 26 & 17 & 9 & 14 \\
\hline 9 & Harar & Harar & 4 & 52 & 36 & 16 & 28 \\
\hline 10 & Jjijiga & Jijiga & 3 & 40 & 28 & 12 & 22 \\
\hline 11 & Harar & Jegol & 1 & 15 & 7 & 8 & 5 \\
\hline & \multicolumn{2}{|c|}{ TOTAL } & & 371 & 242 & 129 & 190 \\
\hline
\end{tabular}

E. Data Collection Instrument

The primary data is collected using a structured questionnaire designed for the purpose of the study. The questionnaire is mainly based on HRD climate questionnaire developed by T. V. Rao. The questionnaire is administered to 190 sample respondents including clerical staff and managers.

\section{F. Data Analysis}

The data collected is analyzed using various statistical tools such as Mean, ANOVA, and chi-square test. Software Package for Social Sciences (SPSS) was used for statistical analysis. A comparative analysis was made between different branches of Commercial Bank of Ethiopia in order to find out if there is a significant difference in HRD climate dimensions between and within different branches using ANOVA. The impact of demographic variables of the respondents on their opinions towards HRD climate dimension was studied using chi-square test.

\section{G. Profile of Sample Respondents}

The profile of the sample respondents is discussed taking into account certain variables like gender, age, marital status, educational qualifications, designation and experience of the respondents.
Table 2: Gender Distribution of the Respondents

\begin{tabular}{|c|c|c|c|c|}
\hline \multirow{2}{*}{ S.NO. } & \multirow{2}{*}{ Particulars } & \multicolumn{2}{|c|}{ Sex } & \multirow{2}{*}{ Total } \\
\cline { 3 - 4 } & Male & Female & \\
\hline 1 & $\begin{array}{c}\text { DISTRICT } \\
\text { OFFICE }\end{array}$ & 11 & 2 & 13 \\
\hline 2 & DIREDAWA & 34 & 16 & 50 \\
\hline 3 & DECHATU & 14 & 5 & 19 \\
\hline 4 & MAGALLA & 11 & 3 & 4 \\
\hline 5 & HARAR & 22 & 6 & 28 \\
\hline 6 & JEGOL & 2 & 3 & 5 \\
\hline 7 & HARAMAYA & 12 & 2 & 14 \\
\hline 8 & CHIRO & 13 & 1 & 14 \\
\hline 9 & DEDDER & 4 & 2 & 6 \\
\hline 10 & HIRNA & 4 & 1 & 5 \\
\hline 11 & JIJIGA & 18 & 4 & 22 \\
\hline \multicolumn{7}{r|}{ TOTAL } & 145 & 45 & 190 \\
\hline \multicolumn{2}{|c|}{ Percentage } & 76.32 & 23.68 & 100 \\
\hline
\end{tabular}

From table 2, it is understood that majority of the respondents $(76.32 \%)$ are male employees in the sample areas of the branches of Commercial Bank of Ethiopia.

Table 3: Age Distribution of the Respondents

\begin{tabular}{|c|c|c|c|c|c|c|}
\hline \multirow[b]{2}{*}{ S.NO. } & \multirow[b]{2}{*}{ Particulars } & \multicolumn{4}{|c|}{ Age(Years) } & \multirow[b]{2}{*}{ Total } \\
\hline & & $21-24$ & $25-29$ & $30-343$ & 35 or older & \\
\hline 1 & $\begin{array}{l}\text { DISTRICT } \\
\text { OFFICE }\end{array}$ & 1 & 6 & 3 & 3 & 13 \\
\hline 2 & DIREDAWA & 3 & 16 & 12 & 19 & 50 \\
\hline 3 & DECHATU & 3 & 4 & 6 & 6 & 19 \\
\hline 4 & MAGALLA & 2 & 4 & 2 & 6 & 14 \\
\hline 5 & HARAR & 6 & 12 & 4 & 6 & 28 \\
\hline 6 & JEGOL & 1 & 2 & 1 & 1 & 5 \\
\hline 7 & HARAMAYA & 2 & 6 & 2 & 4 & 14 \\
\hline 8 & CHIRO & 3 & 5 & 3 & 3 & 14 \\
\hline 9 & DEDDER & 2 & 1 & 1 & 2 & 6 \\
\hline 10 & HIRNA & 3 & 0 & 1 & 1 & 5 \\
\hline & JIJIGA & 5 & 11 & 5 & 1 & 22 \\
\hline & TOTAL & 31 & 67 & 40 & 52 & 190 \\
\hline & Percentage & 16.32 & 35.26 & 21.05 & 27.37 & 100 \\
\hline
\end{tabular}

Table 3 shows the age distribution of the respondents in the sample branches of Commercial Bank of Ethiopia. 35.26\% of respondents are in the age group of 25-29 years, $27.37 \%$ of respondents are in the age group of 35 or older, $21.05 \%$ of respondents are aged between 25 and 29 years and $16.32 \%$ of respondents fall in the age group of 21-24 years. It is observed from table that no particular age group respondents are dominant. 
Table 4: Marital Status of the Respondents

\begin{tabular}{|c|l|c|c|c|c|}
\hline \multirow{2}{*}{ S.N } & \multirow{2}{*}{ Branch/Office } & \multicolumn{3}{|c|}{ Marital status } & \multirow{2}{*}{ Total } \\
\cline { 3 - 5 } & & Divorced & Married & Single & \\
\hline 1 & $\begin{array}{l}\text { DISTRICT } \\
\text { OFFICE }\end{array}$ & 0 & 7 & 6 & 13 \\
\hline 2 & DIREDAWA & 0 & 30 & 20 & 50 \\
\hline 3 & DECHATU & 2 & 8 & 9 & 19 \\
\hline 4 & MAGALLA & 0 & 7 & 7 & 14 \\
\hline 5 & HARAR & 1 & 8 & 19 & 28 \\
\hline 6 & JEGOL & 1 & 2 & 2 & 5 \\
\hline 7 & HARAMAYA & 0 & 7 & 7 & 14 \\
\hline 8 & CHIRO & 0 & 6 & 8 & 14 \\
\hline 9 & DEDDER & 0 & 3 & 3 & 6 \\
\hline 10 & HIRNA & 0 & 1 & 4 & 5 \\
\hline 11 & JIJIGA & 0 & 7 & 15 & 22 \\
\hline \multicolumn{7}{|c|}{ TOTAL } & 4 & 86 & 100 & 190 \\
\hline \multicolumn{7}{|c|}{ Percentage } & 2.11 & 45.26 & 52.63 & 100 \\
\hline
\end{tabular}

From table 4, it is found that majority of the respondents are single, followed by married status while very few respondents are found to be divorced.

Table 5: Educational Qualifications of the Respondents

\begin{tabular}{|c|c|c|c|c|c|c|}
\hline \multirow[b]{2}{*}{ S.NO } & \multirow[b]{2}{*}{ Particulars } & \multicolumn{4}{|c|}{ Educational Qualifications } & \multirow[b]{2}{*}{ Total } \\
\hline & & Diploma & $\begin{array}{c}\text { Gradua } \\
\text { te }\end{array}$ & $\begin{array}{l}P \\
G .\end{array}$ & $\begin{array}{c}\text { Secon } \\
\text { dary }\end{array}$ & \\
\hline 1 & $\begin{array}{c}\text { DISTRICT } \\
\text { OFFICE }\end{array}$ & 6 & 7 & 0 & 0 & 13 \\
\hline 2 & $\begin{array}{c}\text { DIREDA } \\
\text { WA }\end{array}$ & 21 & 22 & 2 & 5 & 50 \\
\hline 3 & $\begin{array}{c}\text { DECHAT } \\
U\end{array}$ & 7 & 11 & 1 & 0 & 19 \\
\hline 4 & $\begin{array}{c}\text { MAGALL } \\
\text { A }\end{array}$ & 8 & 4 & 0 & 2 & 14 \\
\hline 5 & HARAR & 21 & 7 & 0 & 0 & 28 \\
\hline 6 & JEGOL & 1 & 3 & 1 & 0 & 5 \\
\hline 7 & $\begin{array}{c}\text { HARAMA } \\
\text { YA }\end{array}$ & 7 & 5 & 0 & 2 & 14 \\
\hline 8 & CHIRO & 12 & 2 & 0 & 0 & 14 \\
\hline 9 & DEDDER & 3 & 2 & 1 & 0 & 6 \\
\hline 10 & HIRNA & 3 & 1 & 1 & 0 & 5 \\
\hline 11 & JIJIGA & 18 & 2 & 2 & 0 & 22 \\
\hline \multicolumn{2}{|c|}{ TOTAL } & 107 & 66 & 8 & 9 & 190 \\
\hline \multicolumn{2}{|c|}{ Percentage } & 56.32 & 34.74 & $\begin{array}{c}4.2 \\
1\end{array}$ & 4.73 & 100 \\
\hline
\end{tabular}

From table 5, it is observed that majority of the respondents possess diploma as their basic qualification followed by graduation while very few respondents possess secondary and post-graduation level of educational backgrounds.
Table 6: Designations of the Respondents

\begin{tabular}{|c|c|c|c|c|c|c|c|c|c|}
\hline \multirow{2}{*}{ S.No } & \multirow{2}{*}{ Particulars } & \multicolumn{7}{|c|}{ Designation of the Respondents } & \multirow{2}{*}{ Total } \\
\hline & & 1 & 2 & 3 & 4 & 5 & 6 & 7 & \\
\hline 1 & $\begin{array}{l}\text { DISTRICT } \\
\text { OFFICE }\end{array}$ & 0 & 0 & 1 & 0 & 4 & 4 & 4 & 13 \\
\hline 2 & DIREDAWA & 0 & 1 & 9 & 19 & 19 & 0 & 2 & 50 \\
\hline 3 & DECHATU & 1 & 0 & 2 & 5 & 10 & 1 & 0 & 9 \\
\hline 4 & MAGALLA & 0 & 0 & 0 & 6 & 6 & 0 & 2 & 14 \\
\hline 5 & HARAR & 0 & 2 & 1 & 5 & 14 & 0 & 6 & 28 \\
\hline 6 & JEGOL & 1 & 0 & 0 & 1 & 2 & 0 & 1 & 5 \\
\hline 7 & $\begin{array}{l}\text { HARAMAY } \\
\text { A }\end{array}$ & 1 & 0 & 3 & 2 & 8 & 0 & 0 & 14 \\
\hline 8 & CHIRO & 0 & 1 & 3 & 0 & 9 & 0 & 1 & 4 \\
\hline 9 & DEDDER & 1 & 0 & 0 & 2 & 3 & 0 & 0 & 6 \\
\hline 10 & HIRNA & 1 & 0 & 0 & 2 & 2 & 0 & 0 & 5 \\
\hline 11 & JIJIGA & 0 & 0 & 4 & 0 & 15 & 0 & 3 & 22 \\
\hline \multicolumn{2}{|c|}{ TOTAL } & 5 & 4 & 23 & 42 & 92 & 5 & $\begin{array}{l}1 \\
9\end{array}$ & 190 \\
\hline \multicolumn{2}{|c|}{ Percentage } & 2.63 & $\begin{array}{l}2.1 \\
1 \\
\end{array}$ & $\begin{array}{l}12.1 \\
1 \\
\end{array}$ & $\begin{array}{l}22.1 \\
1 \\
\end{array}$ & $\begin{array}{l}48.4 \\
2\end{array}$ & $\begin{array}{l}2.6 \\
3 \\
\end{array}$ & $\begin{array}{l}1 \\
0 \\
\end{array}$ & 100 \\
\hline
\end{tabular}

Note: 1=Branch Manager, 2=Assistant Manager, $3=$ Supervisor, 4=Senior Bank Clerk, 5=Junior Bank Clerk, 6=Others (Secretary and Attorney Designations), 7=Not Specified

Table 6 shows the classification of sample respondents in different branches of Commercial Bank of Ethiopia in the District office based on their designations. All the respondents in the branches are broadly classified into seven major categories which include Branch Managers, Assistant Manager, Supervisor, Senior Bank Clerk, Junior Bank Clerk, and Others. Majority of the respondents are falling in the category of junior bank clerk, followed by senior bank clerk, supervisors etc. while 10 percent of the respondents have not specified their designation.

Table 7: Work Experience of the Respondents

\begin{tabular}{|c|l|l|l|l|l|}
\hline \multirow{2}{*}{ S.No } & \multirow{2}{*}{ Particulars } & \multicolumn{3}{|c|}{ Experience } & \multirow{2}{*}{ Total } \\
\cline { 3 - 5 } & & $0-5$ years & $6-10$ years & 11 and above & \\
\hline 1 & $\begin{array}{l}\text { DISTRICT } \\
\text { OFFICE }\end{array}$ & 5 & 8 & 0 & 13 \\
\hline 2 & DIREDAWA & 18 & 15 & 17 & 50 \\
\hline 3 & DECHATU & 8 & 6 & 5 & 19 \\
\hline 4 & MAGALLA & 7 & 2 & 5 & 14 \\
\hline 5 & HARAR & 21 & 3 & 4 & 28 \\
\hline 6 & JEGOL & 2 & 2 & 1 & 5 \\
\hline 7 & HARAMAYA & 7 & 4 & 3 & 14 \\
\hline 8 & CHIRO & 9 & 3 & 2 & 14 \\
\hline 9 & DEDDER & 3 & 1 & 2 & 6 \\
\hline 10 & HIRNA & 0 & 2 & 3 & 5 \\
\hline 11 & JIJIGA & 20 & 1 & 1 & 22 \\
\hline TOTAL & & 100 & 47 & 43 & 190 \\
\hline
\end{tabular}


\begin{tabular}{|l|l|l|l|l|}
\hline Percentage & 52.63 & 24.74 & 22.63 & 100.00 \\
\hline
\end{tabular}

Table 7 shows the details of the work experience of the respondents in the branches of Commercial Bank of Ethiopia. $52.63 \%$ of the respondents have $0-5$ years of experience, $24.74 \%$ of respondents have $6-10$ years and $22.63 \%$ of respondents have 11 and above years of experience.

\section{RESULTS AND DISCUSSION}

\section{A. HRD Dimensions}

The HRD Climate survey conducted by Rao, T.V. and Abraham, E. (1986) [13], consists of the 38 items that help in assessing the HRD climate in any organization. These 38 items measure "OCTAPAC"- the HRD dimensions in the sample branches of the Commercial Bank of Ethiopia. The term "OCTAPAC" stands for

$\mathrm{O}$ - Openness

C - Confrontation

$\mathrm{T}-$ Trust

A - Autonomy

P - Pro-action

A - Authenticity

C - Collaboration

Table 8: Mean Values of HRD Dimensions in CBE

\begin{tabular}{|c|l|c|}
\hline S.No & HRD Dimensions & $\begin{array}{c}\text { Mean } \\
\text { Value }\end{array}$ \\
\hline 1 & Authenticity & 3.51 \\
\hline 2 & Autonomy & 3.31 \\
\hline 3 & Collaboration & 3.73 \\
\hline 4 & Confrontation & 3.40 \\
\hline 5 & Openness & 3.61 \\
\hline 6 & Pro-action & 3.53 \\
\hline 7 & Trust & 3.67 \\
\hline
\end{tabular}

Table 8 shows the Mean Values of HRD dimensions of CBE in the Dire Dawa District. The mean score for Collaboration is high followed by Trust and Openness whereas the mean score for autonomy is the least among all the HRD dimensions in CBE. Hence, it is understood that the Collaboration among the employees of CBE is high followed by Trust and Openness when compared to autonomy.

\section{A. Branch-Wise Mean Values of HRD Dimension}

In order to study HRD dimensions in different branches, Mean Values are calculated branch-wise for HRD dimensions.

Table 9 Branch-wise Mean Values of Authenticity

\begin{tabular}{|c|l|c|c|c|}
\hline S.No & \multicolumn{1}{|c|}{ Branch } & Mean & $N$ & Std. Deviation \\
\hline 1 & Chiro & 27.00 & 14 & 2.91 \\
\hline 2 & Dechatu & 23.16 & 19 & 3.56 \\
\hline 3 & Magalla & 22.43 & 14 & 4.31 \\
\hline 4 & Dire Dawa & 23.08 & 50 & 3.46 \\
\hline
\end{tabular}

\begin{tabular}{|c|l|c|c|c|}
\hline 5 & District Office & 21.46 & 13 & 6.20 \\
\hline 6 & Dedder & 26.67 & 6 & 4.89 \\
\hline 7 & Haramaya & 24.43 & 14 & 3.88 \\
\hline 8 & Jegol & 25.80 & 5 & 2.49 \\
\hline 9 & Harar & 24.29 & 28 & 4.05 \\
\hline 10 & Hirna & 23.20 & 5 & 1.30 \\
\hline 11 & Jijiga & 22.18 & 22 & 4.39 \\
\hline \multicolumn{2}{|c|}{ Total } & 23.58 & 190 & 4.13 \\
\hline
\end{tabular}

From table 9, it is observed that the mean score for authenticity dimension is higher for Chiro branch compared to other branches and it is low for District Office and so, it can be believed that the employees in Chiro branch have high Authenticity HRD climate dimension compared to other branches. High authenticity is a good feature of successful organization which will lead to the reduction of communication gaps.

Table 10: Branch-wise Mean Values of Autonomy

\begin{tabular}{|c|l|c|c|c|}
\hline S.No & \multicolumn{1}{|c|}{ Branch } & Mean & $N$ & Std. Deviation \\
\hline 1 & Chiro & 7.86 & 14 & 2.07 \\
\hline 2 & Dechatu & 6.11 & 19 & 1.79 \\
\hline 3 & Magalla & 6.50 & 14 & 1.83 \\
\hline 4 & Dire Dawa & 6.26 & 50 & 1.64 \\
\hline 5 & District Office & 6.54 & 13 & 1.66 \\
\hline 6 & Dedder & 7.00 & 6 & 1.41 \\
\hline 7 & Haramaya & 7.36 & 14 & 1.08 \\
\hline 8 & Jegol & 7.00 & 5 & 1.41 \\
\hline 9 & Harar & 6.54 & 28 & 1.43 \\
\hline 10 & Hirna & 8.20 & 5 & 1.92 \\
\hline 11 & Jijiga & 6.36 & 22 & 1.79 \\
\hline & Total & 6.63 & 190 & 1.70 \\
\hline
\end{tabular}

It is observed from table 10, that the mean score for Autonomy dimension in Hirna branch is high and low for Dechatu compared to the other branches in the selected sample area. This indicates that the employees in Hirna branch possess high autonomy compared to the other branches and this improves mutual reverence and results in the willingness of employees in accepting responsibility, taking initiative and also helps in better succession planning. 
Table 11: Branch-wise Mean Values of Collaboration

\begin{tabular}{|c|c|c|c|c|}
\hline S.No & Branch & Mean & $N$ & Std. Deviation \\
\hline 1 & Chiro & 20.21 & 14 & 2.69 \\
\hline 2 & Dechatu & 18.53 & 19 & 2.32 \\
\hline 3 & Magalla & 17.71 & 14 & 4.14 \\
\hline 4 & Dire Dawa & 18.62 & 50 & 2.63 \\
\hline 5 & District Office & 18.23 & 13 & 3.37 \\
\hline 6 & Dedder & 20.33 & 6 & 3.20 \\
\hline 7 & Haramaya & 19.43 & 14 & 3.20 \\
\hline 8 & Jegol & 21.20 & 5 & 2.59 \\
\hline 9 & Harar & 18.57 & 28 & 3.08 \\
\hline 10 & Hirna & 20.40 & 5 & 3.65 \\
\hline 11 & Jijiga & 17.00 & 22 & 3.85 \\
\hline & Total & 18.67 & 190 & 3.18 \\
\hline
\end{tabular}

It is understood from table 11, that the mean score for Collaboration dimension is high for Hirna followed by Dedder, Chiro, etc. and less for Jijiga. The employees in Hirna possess high Collaboration compared to other branches. The result of such high collaboration will lead to helping one another in the timely manner and it also boosts team work among the workers because of the strong communication system adopted at the work place.

Table 12: Branch-wise Mean Values of Confrontation

\begin{tabular}{|c|l|c|c|c|}
\hline S.No & \multicolumn{1}{|c|}{ Branch } & Mean & $N$ & $\begin{array}{c}\text { Std. } \\
\text { Deviation }\end{array}$ \\
\hline 1 & Chiro & 8.36 & 14 & 1.15 \\
\hline 2 & Dechatu & 6.63 & 19 & 1.50 \\
\hline 3 & Magalla & 6.43 & 14 & 1.65 \\
\hline 4 & Dire Dawa & 6.80 & 50 & 1.63 \\
\hline 5 & District Office & 6.54 & 13 & 1.61 \\
\hline 6 & Dedder & 7.50 & 6 & 2.17 \\
\hline 7 & Haramaya & 7.00 & 14 & 1.61 \\
\hline 8 & Jegol & 7.00 & 5 & 1.87 \\
\hline 9 & Harar & 7.07 & 28 & 1.18 \\
\hline 10 & Hirna & 7.60 & 5 & 1.14 \\
\hline 11 & Jijiga & 5.50 & 22 & 1.63 \\
\hline & Total & 6.81 & 190 & 1.64 \\
\hline
\end{tabular}

The better way of handling a problem is to face the problem. From table 12, it is understood that the mean score for confrontation is high in Chiro branch and low for Jijiga branch. The employees in Chiro branch possess high confrontation compared to the other branches and the outcome of high confrontation will lead to the achievement of enhanced role clarity, better problem solving abilities, and in turn it helps handling the problematic customers and workers in the best manner.

Table 13: Branch-wise Mean Values of Openness

\begin{tabular}{|c|l|c|c|c|}
\hline S.No & \multicolumn{1}{|c|}{ Branch } & Mean & $N$ & Std. Deviation \\
\hline 1 & Chiro & 12.14 & 14 & 2.14 \\
\hline 2 & Dechatu & 10.47 & 19 & 1.95 \\
\hline 3 & Magalla & 10.79 & 14 & 2.26 \\
\hline 4 & Dire Dawa & 10.84 & 50 & 2.05 \\
\hline 5 & District Office & 10.38 & 13 & 2.26 \\
\hline 6 & Dedder & 12.83 & 6 & 2.32 \\
\hline 7 & Haramaya & 10.36 & 14 & 2.47 \\
\hline 8 & Jegol & 11.20 & 5 & 0.84 \\
\hline 9 & Harar & 10.64 & 28 & 2.10 \\
\hline 10 & Hirna & 11.80 & 5 & 1.48 \\
\hline 11 & Jijiga & 10.27 & 22 & 2.31 \\
\hline & Total & 10.83 & 190 & 2.16 \\
\hline
\end{tabular}

Openness is the impulsive expression of thoughts and beliefs of people with one another in a welcoming manner. Table 13 clearly explains the 'openness' climate dimension pertaining to 10 branches of Commercial Bank of Ethiopia and the District office in the Diredawa district The employees in Dedder branch possess high openness followed by Chiro branch compared to the other branches. The openness and willingness attitude among the workers result in free interaction which in turn leads to conducive atmosphere and open communication.

Table 14: Branch-wise Mean Values of Pro-action

\begin{tabular}{|c|l|c|c|c|}
\hline S.No & \multicolumn{1}{|c|}{ Branch } & Mean & $N$ & Std. Deviation \\
\hline 1 & Chiro & 41.79 & 14 & 5.94 \\
\hline 2 & Dechatu & 38.26 & 19 & 4.83 \\
\hline 3 & Magalla & 37.29 & 14 & 7.03 \\
\hline 4 & Dire Dawa & 38.24 & 50 & 5.73 \\
\hline 5 & District Office & 37.15 & 13 & 7.15 \\
\hline 6 & Dedder & 41.33 & 6 & 7.76 \\
\hline 7 & Haramaya & 42.00 & 14 & 7.25 \\
\hline 8 & Jegol & 40.80 & 5 & 3.49 \\
\hline 9 & Harar & 38.50 & 28 & 6.40 \\
\hline 10 & Hirna & 41.40 & 5 & 2.41 \\
\hline 11 & Jijiga & 37.64 & 22 & 5.06 \\
\hline & Total & 38.85 & 190 & 6.05 \\
\hline
\end{tabular}


Pro-activeness of efficient work force provides better solutions for the unexpected contingencies and initiates the development of innovative ideas and superior customer satisfaction. Table 14 reveals that the mean score of pro-action is high for Haramaya branch followed by Chiro, Hirna, Dedder, etc. The employees in Haramaya branch are more proactive compared to other employees in the district whereas the employees of District Office are less proactive. Proactivity shows a high level of maturity and both individual employees and the organization can do a lot to promote it.

Table 15: Branch-wise Mean Values of Trust

\begin{tabular}{|c|l|c|c|c|}
\hline S.No & \multicolumn{1}{|c|}{ Branch } & Mean & $N$ & Std. Deviation \\
\hline 1 & Chiro & 32.00 & 14 & 4.52 \\
\hline 2 & Dechatu & 29.05 & 19 & 2.09 \\
\hline 3 & Magalla & 29.00 & 14 & 4.17 \\
\hline 4 & Dire Dawa & 29.30 & 50 & 3.77 \\
\hline 5 & District Office & 28.31 & 13 & 4.21 \\
\hline 6 & Dedder & 31.17 & 6 & 5.94 \\
\hline 7 & Haramaya & 30.50 & 14 & 3.94 \\
\hline 8 & Jegol & 31.60 & 5 & 3.58 \\
\hline 9 & Harar & 28.50 & 28 & 4.08 \\
\hline 10 & Hirna & 31.60 & 5 & 4.51 \\
\hline 11 & Jijiga & 27.91 & 22 & 3.41 \\
\hline \multicolumn{2}{r|}{ Total } & 29.37 & 190 & 3.95 \\
\hline
\end{tabular}

It is understood from table 15 that the mean score of trust for Chiro branch is very high compared to the mean score of other branches. Jijiga is found to possess the lowest mean score value compared to the other branches. The employees in Chiro possess high trust among themselves compared to other branches and this result in higher empathy, timely support, reduced stress, etc. Organizations realized the importance of Trust among the workers and management that will lead to the healthier institutional building processes.

\section{B. Testing of Hypothesis 1}

Null Hypothesis: There are no significant differences in HRD climate dimensions between different branches of Commercial Bank of Ethiopia

Alternate Hypothesis: There are significant differences in HRD climate dimensions between different branches of Commercial Bank of Ethiopia

The hypothesis is tested by calculating ANOVA.

Table 16: ANOVA for HRD Climate Dimensions of CBE Branches

\begin{tabular}{|c|c|c|c|c|c|c|}
\hline $\begin{array}{c}\text { HRD } \\
\text { Dimensions }\end{array}$ & Particulars & $\begin{array}{c}\text { Sum of } \\
\text { Squares }\end{array}$ & Df & $\begin{array}{c}\text { Mean } \\
\text { Square }\end{array}$ & $F$ & Sig. \\
\hline \multirow{2}{*}{ Authenticity } & $\begin{array}{c}\text { Between } \\
\text { Groups }\end{array}$ & 8.28 & 10 & 0.83 & \multirow{2}{*}{2.57} & $\begin{array}{l}\text { Significant } \\
\text { at 1\% level }\end{array}$ \\
\cline { 2 - 6 } & $\begin{array}{c}\text { Within } \\
\text { Groups }\end{array}$ & 57.58 & 179 & 0.32 & & \\
\hline
\end{tabular}

\begin{tabular}{|c|c|c|c|c|c|c|}
\hline & Total & 65.85 & 189 & & & \\
\hline \multirow{3}{*}{ Autonomy } & $\begin{array}{c}\text { Between } \\
\text { Groups }\end{array}$ & 14.14 & 10 & 1.41 & \multirow{3}{*}{2.06} & \multirow{3}{*}{$\begin{array}{l}\text { Significant } \\
\text { at } 5 \% \text { level }\end{array}$} \\
\hline & $\begin{array}{l}\text { Within } \\
\text { Groups }\end{array}$ & 122.98 & 179 & 0.69 & & \\
\hline & Total & 137.12 & 189 & & & \\
\hline \multirow{3}{*}{ Collaboration } & $\begin{array}{c}\text { Between } \\
\text { Groups }\end{array}$ & 7.30 & 10 & 0.73 & \multirow{3}{*}{1.90} & \multirow{3}{*}{$\begin{array}{l}\text { Significant } \\
\text { at } 5 \% \text { level }\end{array}$} \\
\hline & $\begin{array}{l}\text { Within } \\
\text { Groups }\end{array}$ & 68.95 & 179 & 0.39 & & \\
\hline & Total & 76.24 & 189 & & & \\
\hline \multirow{3}{*}{ Confrontation } & $\begin{array}{c}\text { Between } \\
\text { Groups }\end{array}$ & 20.86 & 10 & 2.09 & \multirow{3}{*}{3.52} & \multirow{3}{*}{$\begin{array}{l}\text { Significant } \\
\text { at less than } \\
0.1 \% \text { level }\end{array}$} \\
\hline & $\begin{array}{l}\text { Within } \\
\text { Groups }\end{array}$ & 106.09 & 179 & 0.59 & & \\
\hline & Total & 126.95 & 189 & & & \\
\hline \multirow{3}{*}{ Openness } & $\begin{array}{c}\text { Between } \\
\text { Groups }\end{array}$ & 7.73 & 10 & 0.77 & \multirow{3}{*}{1.54} & \multirow{3}{*}{$\begin{array}{c}\text { Not } \\
\text { significant }\end{array}$} \\
\hline & $\begin{array}{l}\text { Within } \\
\text { Groups }\end{array}$ & 90.12 & 179 & 0.50 & & \\
\hline & Total & 97.85 & 189 & & & \\
\hline \multirow{3}{*}{ Pro-action } & $\begin{array}{c}\text { Between } \\
\text { Groups }\end{array}$ & 4.15 & 10 & 0.42 & \multirow{3}{*}{1.40} & \multirow{3}{*}{$\begin{array}{c}\text { Not } \\
\text { significant }\end{array}$} \\
\hline & $\begin{array}{l}\text { Within } \\
\text { Groups }\end{array}$ & 52.93 & 179 & 0.30 & & \\
\hline & Total & 57.08 & 189 & & & \\
\hline \multirow{3}{*}{ Trust } & $\begin{array}{c}\text { Between } \\
\text { Groups }\end{array}$ & 4.23 & 10 & 0.42 & \multirow{3}{*}{1.81} & \multirow{3}{*}{$\begin{array}{c}\text { Significant } \\
\text { at } 10 \% \\
\text { level }\end{array}$} \\
\hline & $\begin{array}{l}\text { Within } \\
\text { Groups }\end{array}$ & 41.90 & 179 & 0.23 & & \\
\hline & Total & 46.13 & 189 & & & \\
\hline
\end{tabular}

It is understood from Table 16 that the F-values for authenticity, autonomy, collaboration, confrontation and trust dimensions are significant and this indicates that there is significant difference in HRD dimensions between the branches and hence the null hypothesis is rejected and alternate hypothesis is accepted, while F-value is insignificant for openness and pro-action dimensions indicating that openness and pro-action dimensions of HRD climate do not significantly differ between the branches of CBE thus null hypothesis is accepted.

\section{Testing of Hypothesis 2}

Null Hypothesis: There is no significant relationship between demographic variables of the respondents and opinions expressed towards HRD Dimensions.

Alternate Hypothesis: There is significant relationship between demographic variables of the respondents and opinions expressed towards HRD Dimensions.

The hypothesis is tested using chi-square test.

An attempt is made to study the relationship between demographic variables and HRD dimensions. The relationship is examined using chi-square test. The opinions expressed by the respondents may differ depending upon their demographic 
variables. The demographic variables selected for the study include gender, age, marital status, education and experience.

Table 17: Authenticity and Demographic Variables

\begin{tabular}{|c|l|c|c|}
\hline \multirow{2}{*}{ S.No } & \multirow{2}{*}{ Variable } & \multicolumn{2}{|c|}{ Chi-Square Value } \\
\cline { 3 - 4 } & & Value & Significant/Insignificant \\
\hline 1 & Gender & 0.33 & Not Significant \\
\hline 2 & Age & 6.25 & Significant at $10 \%$ \\
\hline 3 & Marital Status & 0.38 & Not Significant \\
\hline 4 & Education & 10.78 & Significant at $1 \%$ \\
\hline 5 & Experience & 7.23 & Significant at $5 \%$ \\
\hline
\end{tabular}

From table 17, it is understood that there is no significant relationship between the variables -gender, marital status of the respondents and the opinion towards authenticity dimension of HRD climate as the chi-square value is insignificant thus the null hypothesis is accepted whereas the chi-square value is significant for age, educational qualifications and experience of the respondent and hence the null hypothesis is rejected and alternate hypothesis is accepted. It implies that opinion towards authenticity dimension of HRD climate is dependent on educational qualifications, experience and age of the respondents.

Table 18: Autonomy and Demographic Variables

\begin{tabular}{|c|l|c|c|}
\hline \multirow{2}{*}{ S. No } & \multirow{2}{*}{ Variable } & \multicolumn{2}{|c|}{ Chi-Square Value } \\
\cline { 3 - 4 } & & Value & Significant/Insignificant \\
\hline 1 & Gender & 1.89 & Not Significant \\
\hline 2 & Age & 7.28 & Not Significant \\
\hline 3 & Marital Status & 2.44 & Not Significant \\
\hline 4 & Education & 16.23 & Significant at $1 \%$ \\
\hline 5 & Experience & 8.79 & Significant at $10 \%$ \\
\hline
\end{tabular}

Table 18 reveals that there is no significant relationship between gender, age, marital status of the respondents and the opinion towards autonomy dimension of HRD climate as the chi-square value is insignificant which means that the null hypothesis is accepted whereas the chi-square value is significant for educational qualifications and experience of the respondent and hence the null hypothesis is rejected and alternate hypothesis is accepted. It is interpreted that respondents with different educational background and of different levels of experience expressed different opinions regarding autonomy dimension of HRD climate.

Table 19: Collaboration and Demographic Variables

\begin{tabular}{|c|l|c|c|}
\hline \multirow{2}{*}{ S.No } & \multirow{2}{*}{ Variable } & \multicolumn{2}{|c|}{ Chi-Square Value } \\
\cline { 3 - 4 } & & Value & Significant/Insignificant \\
\hline 1 & Gender & 6.37 & Significant at 1\% \\
\hline 2 & Age & 11.13 & Significant at $1 \%$ \\
\hline 3 & Marital Status & 0.54 & Not Significant \\
\hline 4 & Education & 6.88 & Significant at $10 \%$ \\
\hline 5 & Experience & 6.34 & Significant at 5\% \\
\hline
\end{tabular}

Table 19 shows the relationship between the collaboration dimension of HRD climate and the demographic variables of the respondents. Gender, age, educational qualifications and experience significantly affect the opinion of the respondents towards the collaboration dimension of the HRD climate resulting in the rejection of the null hypothesis and accepting the alternate hypothesis whereas marital status do not affect and hence the null hypothesis is accepted. It implies that respondents with different age groups, gender, educational qualifications and with different experience levels expressed different opinions regarding collaboration dimension of HRD climate.

Table 20: Confrontation and Demographic Variables

\begin{tabular}{|c|l|c|c|}
\hline \multirow{2}{*}{ S.No } & \multirow{2}{*}{ Variable } & \multicolumn{2}{|c|}{ Chi-Square Value } \\
\cline { 3 - 4 } & & Value & Significant/Insignificant \\
\hline 1 & Gender & 0.31 & Not Significant \\
\hline 2 & Age & 8.63 & Not Significant \\
\hline 3 & Marital Status & 3.89 & Not Significant \\
\hline 4 & Education & 7.06 & Not Significant \\
\hline 5 & Experienc & 4. & Not Significant \\
\hline
\end{tabular}

From table 20, it is observed that there is no significant relationship between any of the demographic variables of the respondents and the opinion towards confrontation dimension of HRD climate as the chi-square value is insignificant which means that the null hypothesis is accepted. It implies that opinion towards confrontation dimension of HRD climate is independent of the demographic variables of the respondents.

Table 21: Openness and Demographic Variables

\begin{tabular}{|c|l|c|c|}
\hline \multirow{2}{*}{ S.No } & \multirow{2}{*}{ Variable } & \multicolumn{2}{|c|}{ Chi-Square Value } \\
\cline { 3 - 4 } & & Value & Significant/Insignificant \\
\hline 1 & Gender & 0.90 & Not Significant \\
\hline 2 & Age & 2.54 & Not Significant \\
\hline 3 & Marital & 2.69 & Not Significant \\
\hline 4 & Education & 2.77 & Not Significant \\
\hline 5 & Experience & 1.92 & Not Significant \\
\hline
\end{tabular}

Table 21 depicts that there is no significant relationship between any of the demographic variables of the respondents and the opinion towards openness dimension of HRD climate as the chi-square value is insignificant. It implies that opinion towards openness dimension of HRD climate is independent of the demographic variables of the respondents and hence the null hypothesis is accepted.

Table 22: Pro-action and Demographic Variables

\begin{tabular}{|c|l|c|c|}
\hline \multirow{2}{*}{ S.No } & \multirow{2}{*}{ Variable } & \multicolumn{2}{|c|}{ Chi-Square Value } \\
\cline { 3 - 4 } & & Value & Significant/Insignificant \\
\hline 1 & Gender & 1.09 & Not Significant \\
\hline 2 & Age & 7.04 & Significant at $10 \%$ \\
\hline 3 & Marital Status & 1.45 & Not Significant \\
\hline 4 & Education & 5.72 & Not Significant \\
\hline 5 & Experience & 3.82 & Not Significant \\
\hline
\end{tabular}


Table 22 shows the opinion of the respondents towards pro-action dimension of HRD climate and the demographic variables of the respondents. Except the age of the respondent, none of the demographic variables do not show any effect upon the opinion of the respondents towards the pro-action dimension of the HRD climate resulting in the acceptance of the null hypothesis. It implies that respondents with different age groups expressed different opinions regarding pro-action dimension of HRD climate.

Table 23: Trust and Demographic Variables

\begin{tabular}{|c|l|c|c|}
\hline \multirow{2}{*}{ S.No } & \multirow{2}{*}{ Variable } & \multicolumn{2}{|c|}{ Chi-Square Value } \\
\cline { 3 - 4 } & & Value & Significant/Insignificant \\
\hline 1 & Gender & 1.86 & Not Significant \\
\hline 2 & Age & 12.78 & Significant at $1 \%$ \\
\hline 3 & Marital Status & 1.37 & Not Significant \\
\hline 4 & Education & 19.20 & Significant at less than $1 \%$ \\
\hline 5 & Experience & 14.36 & Significant at less than $1 \%$ \\
\hline
\end{tabular}

From table 23, it is understood that there is no significant relationship between gender, marital status of the respondents and the opinion towards trust dimension of HRD climate as the chi-square value is insignificant thus the null hypothesis is accepted and contrary to that the chi-square value is significant for age, educational qualifications and experience of the respondent which means that the null hypothesis is rejected and alternate hypothesis is accepted. It implies that opinion towards trust dimension of HRD climate is dependent on age, educational qualification and experience of the respondents.

\section{CONCLUSION}

Present organizations see a paradigm shift with respect to the treatment given to the human resources for the better utilization of their skills, capabilities, talents and aptitudes for the sake of creating the well-developed human resources. Now-a-days, organizations have realized about the importance of improving the effectiveness of HRD Climate through human resource development practices. Commercial Bank of Ethiopia (CBE) is a forward looking organization believing in HRD philosophy and has implemented many HRD dimensions.

The study indicated that employees in CBE are more satisfied with collaboration followed by trust and openness dimensions and relatively less satisfied with autonomy dimension. The results of the study also revealed that there are significant differences among the different branches of CBE with respect to HRD dimensions.

\section{REFERENCES}

[1] B.O. Akinyemi, \& D. Iornem, "Human Resource Development Climate and Employee Commitment in Nigerian Recapitalized Banks", International Journal of Business and Management, Vol. 7, No. 5, 2012.

[2] B.O. Akinyemi, "An Assessment of Human Resource Development Climate in Rwanda Private Sector Organizations", International Bulletin of Business Administration, Vol. X, No. 12, 2011.

[3] K. Anil, "Moving HRD from the Periphery to the Centre for Transformation of an Indian Public Sector Bank: Keynote Address", 4th
Asian Conference of the Academy of HRD-Human Resource Development International, Vol. 10, No. 2, Pp. 203 - 213, 2007.

[4] M. Armstrong and A. Baron, "Strategic HRM: The Key to Improved Business Performance", CIPD, London, 2002.

[5] A.S. Famina, "OCTAPACE Profile and Human Resource Climate in a South Asian Public Sector Undertaking with Special Reference on KSFE", Pranjana, Vol. 12, No 2, 2009.

[6] R. Harrison and J.W.M. Kessels, "Human Resource Development in a Knowledge Economy - An Organizational View", Hampshire - New York: Palgrave Macmillan, 2004.

[7] B. Mohanty, S. Parija and G. Sahu, "An Empirical Study on HRD Climate and its Impact on Job Performance in Private Insurance Companies in Odessa", Zenith International Journal of Multidisciplinary Research, Vol. 2, No. 5, 2012.

[8] E. Petridou and N. Glaveli, "Human Resource Development in a Challenging Financial Environment: The Case of a Greek Bank", HRD International, Vol. 6, No.4, Pp. 547-558, 2003.

[9] T.V. Rao and E. Abraham, "Integrated Human Resource Development Systems", In Rao, T.V. and D.F. Pereira, (ed.) Recent Experiences in Human Resource Development, Oxford and IBH, New Delhi. 68, 1986.

[10] R. Riyaz, "HRD Climate in Commercial banks: An Empirical study", The Business Review, Vol. 9, No.1, 2002.

[11] S. Saraswathi, "Human Resources Development Climate: An Empirical Study," International Journal of Innovation, Management and Technology, Vol. 1, No. 2, Pp. 174-179, 2010.

[12] K. Saxena and P. Tiwari, "HRD Climate in Selected Public Sector Banks: An Empirical Study", 9th Global Conference on Business and Economics, Cambridge University, UK, 2009.

[13] M. Srimannarayana, "Human Resource Development Climate in a Dubai Bank", ICFAI Journal of Organizational Behavior, Vol. 6, No. 1, 2007.

[14] R.A. Swanson, "Human Resource Development and its Underlying Theory", Human Resource Development International, Vol. 4, No. 3, Pp. $299-312,2001$.

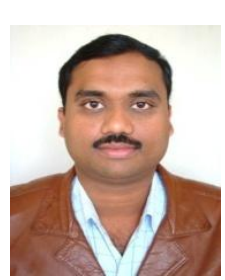

Mr. K. Anil Kumar is working as a lecturer in the Department of Business Studies, Ibra College of Technology, Al-Sharqiyah North Governorate, Ibra, Sultanate of Oman. He has 13 years of teaching experience along with the research knowledge. His area of expertise is Human Resource Management and Marketing. He has attended many conferences, a staff development program and published few papers in national and international referred journals. 